\title{
ГІДРОТЕХНІКА
}

Новачок О. М., к.с.-г.н., доцент, Новачок А. Р., студент (Національний університет водного господарства та природокористування, м. Рівне), Новачок I. О., магістр (Національний університет водного господарства та природокористування, м. Рівне)

\section{ПРОГРАМНЕ ЗАБЕЗПЕЧЕННЯ ГІДРОІНФОРМАТИКИ}

Проблеми, пов'язані з водою, вважаються одними 3 найбільш серйозних проблем, що стоять перед людством в нинішньому столітті. Стало очевидним, що доступність води в світі зменшується через надмірне споживання, забруднення водоносних горизонтів, неадекватне управління відходами, відсутність належної технології збору та розподілу води і надмірне землеробство. $€$ численні повідомлення про те, що більше 1 мільярда людей у країнах, що розвиваються не мають доступу до безпечної питної води та майже 3 мільярди не мають доступу до адекватних санітарно-технічних засобів. Зміна клімату також стала серйозним фактором: зі зміною в характері опадів традиційні водні системи все менше і менше ефективні. Незважаючи на те, що наші технологічні можливості для боротьби 3 гідрометеорологічними явищами швидко просунулися за останні сто років, такі події стають все більш катастрофічними. Гідроінформатика пропонує значні можливості вирішити деякі з цих проблем, пов'язаних з водою, шляхом інтеграції даних, моделей і підтримки прийняття рішень. В роботі представлено результати аналізу сучасного програмного забезпечення, яке використовується в гідроінформатиці.

Ключові слова: гідроінформатика, гідродинаміка, математичне моделювання, програмне забезпечення, інформаційні технології, водне господарство.

Вступ. Гідроінформатика - це дисципліна та технологія, що стосується використання досягнень у галузі інформаційно-комунікаційних технологій, комп'ютерних наук та штучного інтелекту для вирішення проблем водного середовища. Попередником гідроінформатики $\epsilon$ обчислювальна гідродинаміка [1] (також CFD від англ. Computational fluid dynamics) - галузь механіки суцільних середовищ, що включає сукупність фізичних, математичних і чисельних ме- 
тодів, призначених для обчислення характеристик потокових процесів. Динаміка рідини, є активним полем дослідження, як правило, математично складним. Багато проблем частково або цілком не вирішені, і їх краще вирішувати чисельними методами з використанням комп'ютерів.

Кожен день супутники Terra і Aqua розгорнуті НАСА (Національне управління $з$ аеронавтики і дослідження космічного простору) зби-рають кілька терабайт даних, пов'язаних з безліччю змінних атмосфери і поверхні суші Землі. Ці дані в даний час потрапляють в моделі, які потім забезпечують динамічно узгоджений набір значень для спостережу-ваних змінних (або станів). Кращі рішення можуть бути досягнуті на високошвидкісних суперкомп'ютерах.

3 технічної сторони, крім обчислювальної гідродинаміки, гідроінформатика має великий інтерес до використання методів, що походять зі штучного інтелекту: штучні нейронні мережі, глибоке навчання та генетичне програмування. Вони можуть бути використані 3 великими наборами спостережуваних даних з метою інтелектуального аналізу даних для виявлення знань, або з даними, отриманими з існуючої фізичної моделі, щоб генерувати ефективний обчислювальний емулятор цієї моделі з певними цілями.

Метою гідроінформатики є перетворення соціального середовища з пасивного, (в якому кожна зацікавлена сторона реагує індивідуально на чисто технічну трансформацію і виключно на основі безпосередніх соціальних наслідків для цієї зацікавленої сторони) в інтерактивну (в якій кожен учасник взаємодіє з іншими зацікавленими сторонами в рамках спільноти, в результаті чого різні зацікавлені сторони приходять до співпраці та формування трансформації в цілому, перетворення її в по суті соціотехнічну трансформацію) [2].

Завдяки універсальності підходу сфера застосування гідроінформатики дуже широка: річкові басейни, управління водними ресурсами, управління підземними водами, управління ризиками повені, оптимізація пласта, управління прибережними системами, системи навколишнього середовища, гідромеліоративні системи, міські системи водопостачання та ін. Гідроінформатика має застосування у всіх точках кругообігу води від атмосфери до океану, надає підтримку у прийнятті рішень на всіх рівнях управління та політики.

Гідроінформаційна спільнота. Перша у світі магістерська програма з гідроінформатики розпочалася в 1991 році в Інституті водної освіти Делфта (Нідерланди) (IHE Delft Institute for Water Education) (раніше UNESCO-IHE) [3]. Уявлення про сучасну лабораторію гідроін- 
форматики можна отримати відвідавши сайти лабораторії гідроінформатики UI в Університеті штату Айова [4] та Європейський інформаційний сайт з гідроінформатики [5].

В 2001 році заснований один з найбільших світових центів розвитку гідроінформатики - Консорціум університетів з розвитку гідрологічної науки Consortium of Universities for the Advancement of Hydrologic Science (CUAHSI), який об'єднує більше 130 університетів США [6].

В 2004 році створений консорціум EuroAquae+ в рамках Erasmus Mundus. До складу EuroAquae+ входять: Університет Ніцци (University of Nice - Sophia Antipolis (UNS, France)), Технічний університет Каталонії (Technical University of Catalonia (UPC, Spain)), Бранденбурзький технічний університет (Brandenburg University of Technology at Cottbus (BTUC, Germany)), Університет Ньюкасла (Newcastle University (NU, United Kingdom)), Варшавський технологічний університет (Warsaw University of Technology (WUT, Poland)) [7].

Програмне забезпечення. Одним зі світових центрів гідрологічних досліджень, програмне забезпечення якого можна використовувати безкоштовно, є гідрологічний інженерний центр (CEIWR-HEC) інженерного корпусу при армії США (The U.S. Army Corps of Engineers - USACE), який був утворений в 1964 році. Сімейство програмного забезпечення цього центру має більше двадцяти основних програм. CEIWR-HEC, мабуть, найвідоміша серед інженерних програм водогосподарського призначення, має відділи: гідрології та гідравліки, систем використання водних ресурсів, систем управління водними ресурсами. Недавні досягнення включають в себе: розвиток наступного покоління програмного забезпечення CEIWR-HEC (HEC-RAS, HECHMS, HEC-FDA, і HEC-ResSim); аналіз ризиків для зменшення шкоди від повеней; розробку та впровадження системи управління водними ресурсами (CWMS), системи прогнозування і підтримки прийняття рішень в режимі реального часу, в режимі 24/7 при виконанні місії водного контролю та управлінні водними ресурсами USACE [8].

\section{Hydrologic Engineering Center River Analysis System (HEC-RAS)}

Пакет HEC-RAS призначений для одно- і двомірних гідравлічних розрахунків для мережі природних і побудованих каналів.

Система HEC-RAS містить кілька компонентів аналізу річки для, обчислень профілю поверхні води безперервного потоку, одно- i двомірного моделювання нестаціонарних течій, обчислення транспортування наносів, аналізу якості води. Всі чотири компоненти використовують загальну геометричну модель даних і загальні геомет- 
ричні та гідравлічні процедури обчислення. На додаток до цих компонентів аналізу річок, система містить кілька гідравлічних конструктивних особливостей, які можуть бути викликані після обчислення основних профілів поверхні води. Система може обробляти повну мережу каналів, дендритних систем, ділянок річок.

Основна обчислювальна процедура заснована на розв'язку одновимірного рівняння енергії. Оцінюються втрати енергії від тертя (рівняння Меннінга) і стиснення / розширення (коефіцієнт множиться на зміну швидкісного напору). Рівняння імпульсів може бути використано в тих випадках, коли профіль поверхні води швидко змінюється. Ці ситуації включають в себе розрахунки змішаних режимів потоку, гідравліку мостів, а також оцінки профілів на притоках річок.

HEC-RAS може імітувати одновимірний, двовимірний і комбінований нестаціонарний потік через повну мережу відкритих каналів, заплав і алювіальних наносів. Особливості компонента нестаціонарних течій включають в себе: великі гідравлічні можливості аналізу структури прориву греблі; переливу; насосних станцій; напірних трубопровідних систем; автоматизовані функції калібрування.

HEC-RAS може моделювати одновимірне транспортування наносів в результаті розмиву і осаду за тривалі періоди часу (як правило, роки). Осадовий транспортний потенціал обчислюється за розміром зерен фракції, дозволяючи моделювання гідравлічного сортування. Основні функції включають в себе можливість моделювати повну мережу потоків, днопоглиблення каналу, а також використання декількох різних рівнянь для розрахунку наносів.

Модель призначена для імітації довгострокових тенденцій розмиву і осаду в потоці каналу, який може виникнути в результаті зміни частоти і тривалості скидання води, або зміни геометрії каналу. Ця система може бути використана для оцінки осаду в резервуарах, каналах, які необхідні для підтримки навігаційних глибин, передбачення впливу днопоглиблювальних робіт на швидкість осаду, оцінки максимально можливого розмиву під час великих повеней, а також оцінки осідання в фіксованих каналах.

Аналіз якості води. Цей компонент системи моделювання призначений для аналізу якості річкової води. Модуль що входить в склад HEC-RAS, дає можливість моделювати температуру води. Цей модуль використовує QUICKEST-ULTIMATE явну чисельну схему для розв'язку одновимірного рівняння адвекції-дисперсії з використанням об'ємного контролю повністю реалізованого бюджету теплової енергії. Наявні в даний час складові якості води: розчинений азот; 
розчинений фосфор; водорості; розчинений кисень; і карбонатне біологічне споживання кисню.

Графіка і звітність. Графіка включає XY ділянки річкової системи, схеми перетину, профілі, рейтингові криві, гідрографи, і відображення затоплення. Передбачені тривимірні ділянки поперечних перерізів. Відображення затоплення здійснюється в HEC-RAS Mapper. Карти затоплень можуть бути анімованими, і містять кілька фонових шарів (місцевості, аерофотозйомки...). Доступний табличний вивід. Користувачі можуть вибрати одну із передбачених таблиць, або розробляти свої власні індивідуальні таблиці. Всі графічні і табличні результати можуть бути відображені на екрані, роздруковуватись або передаватись через буфер обміну Windows іншому програмному забезпеченню, такому як текстовий процесор або електронна таблиця.

Пакет Hydrologic Modeling System (HEC-HMS) призначений для повної імітації гідрологічних процесів деревовидних систем водозбору. Програмне забезпечення включає в себе традиційні процедури гідрологічного аналізу, такі як інфільтрація, гідрографи, гідрологічна маршрутизація. HEC-HMS також включає в себе процедури, необхідні для безперервного моделювання, включаючи евапотранспірацію, сніготанення та облік вологості ґрунту. Розширені можливості передбачають моделювання з координатною прив'язкою поверхневого стоку з використанням лінійного перетворення квазі-розподіленого стоку (ModClark). Додаткові інструменти аналізу призначені для оптимізації моделі, прогнозування річкового стоку, зменшення глибини зони, оцінки невизначеності моделі, ерозії, наносів і якості води.

Програмне забезпечення має повністю інтегроване робоче середовище, в тому числі бази даних, утиліти для введення даних, блок обчислення та інструменти звітності. Графічний користувацький інтерфейс дозволяє користувачеві безперешкодне переміщення між різними частинами програмного забезпечення. Результати моделювання зберігаються в HEC-DSS (системі зберігання даних) і можуть бути використані в поєднанні з іншим програмним забезпеченням для досліджень доступності водних ресурсів, міського дренажу, прогнозування повеней, майбутніх наслідків урбанізації, проектування водосховищ, зменшення шкоди від повеней, заплавного регулювання...

Водозбір. Фізичне представлення водозбору здійснюється за допомогою моделі басейну. Гідрологічні елементи з'єднані в дендритній (деревовидній) мережі для моделювання процесів поверхневого стоку. Доступні елементи: суббасейн, вузол, резервуар, джерело, 
стік, розрахункові витрати вниз по течії.

Асортимент різних методів доступний для моделювання втрат інфільтрації. Одношаровий метод може бути використаний для простого безперервного моделювання. Тришаровий метод обліку вологості ґрунту може бути використаний для безперервного моделювання складної інфільтрації та евапотранспіраціі. Включені сім методів для перетворення надлишкових опадів в поверхневий стік. Включені п'ять методів для визначення вкладів основного потоку в відтік суббасейну. Метод дає експоненціально спадаючу межень від однієї події або декількох послідовних подій. Постійний щомісячний метод може добре працювати для безперервного моделювання. Метод лінійного резервуара зберігає масу шляхом маршрутизації інфільтрації опадів у канал. Нелінійний метод Бусінеска забезпечує відгук, аналогічний методу спаду, але параметри можуть бути оцінені з вимірюваних характеристик вододілу.

Шість гідроіндікаторів методів маршрутизації включені для моделювання потоку у відкритих каналах. Маршрутизація без ослаблення може бути змодельована за допомогою методу запізнювання.

Метеорологія. Аналіз метеорологічних даних включає в себе короткохвильове випромінювання, опади, евапотранспірацію і сніготанення. Не всі ці компоненти необхідні для всіх моделей. Просте моделювання подій вимагають тільки кількість опадів, в той час як безперервне моделювання додатково вимагає евапотранспірацію. Сніготанення потрібно тільки при роботі з водозбірними басейнами в умовах холодного клімату. Включені чотири різні методи для аналізу історичних опадів. Включені п'ять різних методів отримання синтетичних опадів. Частотний метод шторму використовує статистичні дані для створення збалансованих штормів з певною ймовірністю перевищення. Джерела підтримки включають в себе статистичні дані Департаменту торгівлі США, Національної служби погоди (NWS), Національного управління океанічних і атмосферних досліджень (NOAA), Atlas 2 i Atlas 14.

Потенціал випаровування вологи можна обчислити за допомогою щомісячних середніх значень. Існує також реалізація методу Прістлі-Тейлора. Доступний варіант географічної координатної прив'язки методу Прістлі-Тейлора, де необхідні параметри температури і сонячної радіації визначаються на основі координатної прив'язки. Метод Пенман-Монтейт використовує баланс енергії на поверхні землі. Метод заданий користувачем може бути використаний з даними розробленими на основі аналізу за межами програми. 
Сніготанення може бути включене для відстеження накопичення і танення в сніговому покриві. Доступний метод температурного індексу, який динамічно обчислює швидкість танення, ґрунтуючись на поточних атмосферних умовах і минулих умовах в сніговому покриві.

Гідрологічне моделювання. Проміжок часу моделювання контролюється специфікаціями управління. Характеристики управління включають в себе початкову дату і час, кінцеву дату і час, а також інтервал часу. У робочому циклі моделювання створюється шляхом об'єднання моделі басейну, метеорологічних моделей і специфікації управління. Виконувані варіанти включають опади, потоки, можливість зберігати всю інформацію про стан басейну в певний момент часу, а також можливість відновлення моделювання з раніше збереженого стану.

Результати моделювання можна розглядати з карти басейну. Всі графіки і таблиці можуть бути надруковані.

Модель оптимізації. Більшість параметрів методів, включених в суббасейн можуть бути оцінені автоматично з допомогою оптимізації випробувань. Можуть бути оцінені параметри на будь-якому елементі вище за течією від місця спостережуваного потоку. Сім різних цільових функцій доступні для оцінки узгодженості між розрахованими результатами і спостережуваними даними. Існують два методи пошуку, які можуть бути використані для мінімізації цільової функції. Обмеження можуть бути накладені обмеженням простору параметрів методу пошуку.

Руслове прогнозування. Модель басейну включає в себе функції, призначені для покращення прогнозів майбутніх потоків в режимі реального часу. Зони можуть бути створені на основі аналогічних гідрологічних умов або регіональних особливостей. Зони можуть бути призначені окремо для швидкості втрати, перетворення, межені і маршрутизації каналу. Альтернативний ппрогноз є типом моделювання, який використовує модель басейну і метеорологічні моделі в поєднанні з параметрами управління для прогнозування майбутніх потоків.

ГIC Підключення. HEC-HMS дає можливість представляти вододіли з сотнями елементів гідроіндікаторів. Традиційно, ці елементи будуть визначені шляхом перевірки топографічної карти і ручної ідентифікації границь. Хоч цей метод ефективний, він вимагає багато часу, поки вододіл буде представлений з багатьма елементами. Географічна інформаційна система (ГІС) може використовувати висотні 
відмітки даних і геометричні алгоритми для виконання того ж завдання набагато швидше. ГІС компаньйон продукт був розроблений , щоб допомогти в створенні басейнових моделей для таких проектів. Цей допоміжний продукт (HEC-GeoHMS), і може бути використаний для створення басейнових та метеорологічних моделей для використання з програмою.

\section{SWAT (Soil \& Water Assessment Tool)}

Управління водними ресурсами потребує моделювання гідрологічних процесів, таких як інфільтрація, стік підземних вод, поверхневий стік, евапотранспірація тощо. В останні роки для оцінки водних ресурсів під впливом зміни клімату та діяльності людини все частіше використовуються розподілені гідрологічні моделі, оскільки вони можуть представляти реальні гідрологічні процеси. Модель сільськогосподарських неточкових джерел (AGNPS), модель гідрологічного інженерного центру (HEC-HMS), програма гідрологічного моделювання-Fortran (HSPF), MIKE SHE та SWAT, успішно застосовувались в басейнах багатьох річок світу.

Інструмент оцінки ґрунту та води SWAT (Soil \& Water Assessment Tool) [9] - це модель масштабу річкового басейну, розроблена доктором Джеффом Арнольдом (Dr. Jeff Arnold) для кількісної оцінки впливу землевпорядкування на великі, складні водозбори на замовлення Служби сільськогосподарських досліджень USDA в Blackland Research \& Extension Center у Темпл, США. SWAT - це гідрологічна модель з наступними компонентами: погода, поверхневий стік, зворотний потік, перколяція, евапотранспірація, втрати при передачі, водосховища, формування врожаю та зрошення, потік підземних вод, маршрутизація, завантаження поживних речовин і пестицидів і передача води. SWAT - це модель, що підтримує вільне програмне забезпечення.

SWAT був розроблений для прогнозування впливу внесення хімічних добрив, землекористування на якість води, донні відкладення, врожаї сільськогосподарських культур у великих комплексних водозборах з різними ґрунтами та умовами сільськогосподарського використання протягом тривалого часу. Замість включення рівнянь регресії для опису взаємозв'язку між вхідними та вихідними змінними, для досягнення цієї мети була створена фізична модель. SWAT вимагає спеціальної інформації про погоду, властивості грунтів, топографію, рослинність та сільськогосподарське виробництво на вододілі. Фізичні процеси, пов'язані з рухом води, рухом донних відкладень, ростом врожаю, кругообігу поживних речовин та ін. 
Перевагою такого підходу $є$ те, що водозбори без даних моніторингу, можуть бути змодельовані відносно впливу альтернативних вихідних даних (наприклад, зміни сільськогосподарського виробництва, клімату, рослинності тощо) на якість води або інші змінні. Хоча SWAT може бути використаний для вивчення більш спеціалізованих процесів, таких як транспортування бактерій, мінімальні дані, необхідні для виконання циклу, зазвичай доступні від державних установ.

Допускається моделювання великих басейнів. Різноманітність стратегій управління може бути виконана без надмірних інвестицій часу або грошей, дозволяє користувачам вивчати довгострокові наслідки. Багато проблем, які в даний час розглядаються користувачами, включають поступове нарощування забруднюючих речовин та вплив на водойми нижнього б'єфу. Щоб вивчити ці типи проблем, потрібні результати від циклів з виходом на декілька десятиліть.

SWAT - це модель реального часу. Модель не призначена для моделювання детальної маршрутизації повені з одноразовою подією.

SWAT використовується в усьому світі і постійно розвивається. Станом на липень 2012 року було опубліковано понад 1000 рецензованих статей, що документують різні його застосування..

Розроблений в 2015 році пакет WaterML R (для мови програмування R), надає доступ до даних інформаційної системи HydroServer Консорціуму університетів з розвитку гідрологічної науки Consortium of Universities for the Advancement of Hydrologic Science (CUAHSI) [6]. WaterML R дозволяє науковцям-дослідникам користуватися статистичним обчислювальним середовищем R разом з програмним забезпеченням з відкритим вихідним кодом HydroServer (для архівування та обміну даними). Користуючись пакетом WaterML R, користувач може отримати та проаналізувати дані від HydroServers з сотень організацій, які перелічені в каталозі центру обробки даних CUAHSI та у глобальному каталозі даних Всесвітньої Метеорологічної Організації.

WaterML - це технічна норма і інформаційна модель, яка використовується для представлення гідрологічних структур часових рядів. Поточна версія WaterML 2.0. WaterML 2.0 - це відкритий стандарт, який гармонізує різні формати з різних організацій і країн, з існуючими форматами Open Geospatial Consortium (OGC). WaterML 2.0 був прийнятий як офіційний стандарт OGC у вересні 2012 року, схвалений Федеральним комітетом географічних даних США, і був запропонований для прийняття Світовою метеорологічною організацією World Meteorological Organisation (WMO). 
Структура WaterML 2.0 використовує існуючі стандарти OGC, насамперед спостереження та вимірювання (0\&M) та географічну мову розмітки (GML). Це підвищує узгодженість та сумісність з іншими стандартами та веб-службами. Використовуючи стандарт 0\&M, WaterML 2.0 визначає типи, що дозволяють стандартне визначення основних властивостей, що відносяться до гідрологічних часових рядів.

$\mathbf{R}$ - мова програмування і середовище вільного програмного забезпечення для статистичних обчислень і графіки, що підтримуються R Foundation for Statistical Computing. Мова R широко використовується для статистики та інтелектуального аналізу даних, для розробки статистичного програмного забезпечення. Опитування, дослідження інтелектуального аналізу даних і дослідження літератури наукових баз даних показують значне збільшення популярності в останні роки. Станом на березень 2019 р. R посідає 14 місце в індексі TIOBE (міра популярності мов програмування) [10].

Можливості R розширюються через створювані користувачем пакети, які дозволяють спеціалізовані статистичні методи, графічні пристрої, можливості імпорту та експорту, інструменти звітності. Ці пакети розробляються в основному в R, а іноді і в Java, C, C ++ i Fortran.

Основний набір пакетів включено при встановленні R, з більш ніж 15000 додаткових пакетів (станом на вересень 2018), доступних у Всеохопній мережі архівів Comprehensive R Archive Network (CRAN), Bioconductor, Omegahat, GitHub та інших.

Сторінка «Task Views» на веб-сайті CRAN перелічує широкий спектр завдань для яких доступні пакети $\mathrm{R}$ (у таких галузях, як фінанси, генетика, високопродуктивні обчислення, машинне навчання, медичні зображення, соціальні науки та просторова статистика). $\mathrm{R}$ також був визначений FDA як придатний для інтерпретації даних клінічних досліджень.

Інші ресурси R-пакета включають Crantastic, сайт спільноти для оцінки та перегляду всіх CRAN-пакетів, R-Forge, центральну платформу для спільної розробки пакетів R, R-програм і проектів. У R-Forge також розміщено багато неопублікованих бета-пакунків, а також розробки версій пакетів CRAN.

Висновок. Над вирішенням водних проблем, розвитком гідроінформатики, працюють тисячі організацій і колективів вчених у всьому світі. Розроблено десятки тисяч одиниць програмного забезпечення. Для початківця це створює певні труднощі. Рекомендується використовувати найбільш вживане, апробоване програмне забез- 
печення. Наголос зроблено на вільне та безкоштовне програмне забезпечення.

1. Abbott, M. B. Hydroinformatics: Information Technology and the Aquatic Environment; Ashgate (later Avebury): Aldershot, UK; Brookfield, VT, USA, 1991. 2. Abbott, M. B. The sociotechnical dimension of hydroinformatics. In Proceedings of the Second International Conference on Hydroinformatics, Zürich, Switzerland, 9-13 September 1996. Рp. 3-18. 3. Сайт Інституту водної освіти Делфта. URL: https://www.un-ihe.org/ (дата звернення: 24.03.2019). 4. Сайт лабораторії гідроінформатики UI в Університеті штату Айова. URL: https://hydroinformatics.uiowa.edu/ (дата звернення: 24.03.2019). 5. Європейський інформаційний сайт 3 гідро інформатики. URL: http://www.hydroinformatics.org/index.php (дата звернення: 24.03.2019). 6. Сайт консорціуму університетів для покращення гідрологічної науки (CUAHSI). URL: https://www.cuahsi.org/about/what-is-cuahsi/ (дата звернення: 24.03.2019). 7. Сайт консорціуму EuroAquae+ URL: http://master.euroaquae.eu/ (дата звернення: 24.03.2019). 8. Сайт гідрологічного інженерного центру інженерного корпусу при армії США (CEIWR-HEC). URL: http://www.hec.usace.army.mil/ (дата звернення: 24.03.2019). 9. Сайт розробників системи SWAT (Soil \& Water Assessment Tool). URL: https://swat.tamu.edu/ (дата звернення: 24.03.2019). 10. Сайт розробників мови програмування R, програмного середовища для статистичних обчислень, аналізу та представлення даних в графічному вигляді. URL: https://cran.r-project.org/ (дата звернення: 24.03.2019).

\section{REFERENCES:}

1. Abbott, M. B. Hydroinformatics: Information Technology and the Aquatic Environment; Ashgate (later Avebury): Aldershot, UK; Brookfield, VT, USA, 1991. 2. Abbott, M. B. The sociotechnical dimension of hydroinformatics. In Proceedings of the Second International Conference on Hydroinformatics, Zürich, Switzerland, 9-13 September 1996. Pp. 3-18. 3. Sait Instytutu vodnoi osvity Delfta. URL: https://www.un-ihe.org/ (data zvernennia: 24.03.2019). 4. Sait laboratorii hidroinformatyky UI $v$ Universyteti shtatu Aiova. URL: https://hydroinformatics.uiowa.edu/ (data zvernennia: 24.03.2019). 5. Yevropeiskyi informatsiinyi sait $z$ hidro informatyky. URL: http://www.hydroinformatics.org/index.php (data zvernennia: 24.03.2019). 6. Sait konsortsiumu universytetiv dlia pokrashchennia hidrolohichnoi nauky (CUAHSI). URL: https://www.cuahsi.org/about/what-is-cuahsi/ (data zvernennia: 24.03.2019). 7. Sait konsortsiumu EuroAquae+ URL: http://master.euroaquae.eu/ (data zvernennia: 24.03.2019). 8. Sait hidrolohichnoho inzhenernoho tsentru inzhenernoho korpusu pry armii SShA (CEIWR-HEC). URL: http://www.hec.usace.army.mil/ (data zvernennia: 24.03.2019). 9. Sait rozrobnykiv systemy SWAT (Soil \& Water Assessment Tool). URL: https://swat.tamu.edu/ (data zvernennia: 24.03.2019). 10. Sait rozrobnykiv movy prohramuvannia $R$, prohramnoho seredovyshcha dlia 
statystychnykh obchyslen, analizu ta predstavlennia danykh $\mathrm{v}$ hrafichnomu vyhliadi. URL: https://cran.r-project.org/ (data zvernennia: 24.03.2019).

Novachok O. M., Candidate of Agricultural Sciences (Ph.D.), Associate Professor, Novachok A. R., Senior Student (National University of Water and Environmental Engineering, Rivne), Novachok I. O., Master (National University of Water and Environmental Engineering, Rivne)

\section{HYDROINFORMATICS SOFTWARE}

Water related problems are ranked as some of the greatest problems facing mankind in the present century. It has become evident that the world's availability of water is reduced due to excessive consumption, contamination of aquifers, inadequate waste management, lack of proper water collection and distribution technologies, and excessive farming. There are numerous reports that over 1 billion people in developing countries lack access to safe drinking water and almost 3 billion have no access to adequate sanitation facilities. Climate change has also become a challenging factor: changes in rainfall patterns are making traditional water systems less and less effective (e.g., drainage and flood protection, water control, storage and distribution facilities and so on). Despite the fact that our technological capabilities for dealing with hydro-meteorological events have advanced rapidly over the last hundred years and while global economic growth per capita has doubled, such events have become ever more disastrous. Modelling in fluid mechanics, hydraulics and hydrology, whether using digital tools or scale models, has reached sufficient maturity to be in daily use by engineers for analysis, design and for communication. Increasingly, complex cases can be handled thanks to ever-more sophisticated tools and increasingly abundant computing power. The emerging environment populated with new generation of sensors, using cloud-computing resources, is challenging the current practices of modelling and request innovation in methodology and concepts for a real integration into the decisionmakings processes. At the same time, the request to integrate vulnerability and resilience dimension in the various engineering approaches is becoming more and more frequent. Hydroinformatics offers a considerable opportunity to address some of these waterrelated issues in a way that it can meaningfully provide integration between data, models and decision support. The paper presents the 
results of the analysis of modern software used in hydroinformatics. Keywords: hydroinformatics, hydrodynamics, mathematical modeling, software, information technologies, water management.

Новачок А. М., к.с.-Х.н., доцент, Новачок А. Р., студент (Национальный университет водного хозяйства и природопользования, г. Ровно), Новачок И. А., магистр (Национальный университет водного хозяйства и природопользования, г. Ровно)

\section{ПРОГРАММНОЕ ОБЕСПЕЧЕНИЕ ГИДРОИНФОРМАТИКИ}

Проблемы, связанные с водой, считаются одними из самых больших проблем, стоящих перед человечеством в нынешнем столетии. Стало очевидным, что доступность воды в мире уменьшается из-за чрезмерного потребления, загрязнения водоносных горизонтов, неадекватного управления отходами, отсутствия надлежащих технологий сбора и распределения воды и чрезмерного ведения сельского хозяйства. Есть многочисленные сообщения о том, что более 1 миллиарда человек в развивающихся странах не имеют доступа к безопасной питьевой воде и почти 3 миллиарда не имеют доступа к адекватным санитарно-техническим средствам. Изменение климата также стало серьезным фактором: изменения в структуре осадков делают традиционные системы водоснабжения все менее и менее эффективными (например, защита от наводнений, контроль водоснабжения, хранение и распределение воды). Несмотря на то, что наши технологические возможности для борьбы с гидрометеорологическими явлениями быстро развивались в течение последних ста лет, и хотя глобальный экономический рост на душу населения удвоился, такие события стали еще более катастрофическими. Гидроинформатика предлагает значительную возможность для решения некоторых из этих проблем, связанных с водой, таким образом, чтобы она могла обеспечить полноценную интеграцию между данными, моделями и поддержкой принятия решений. В статье представлены результаты анализа современного программного обеспечения, используемого в гидроинформатике.

Ключевые слова: гидроинформатика, гидродинамика, математическое моделирование, программное обеспечение, информационные технологии, водное хозяйство. 